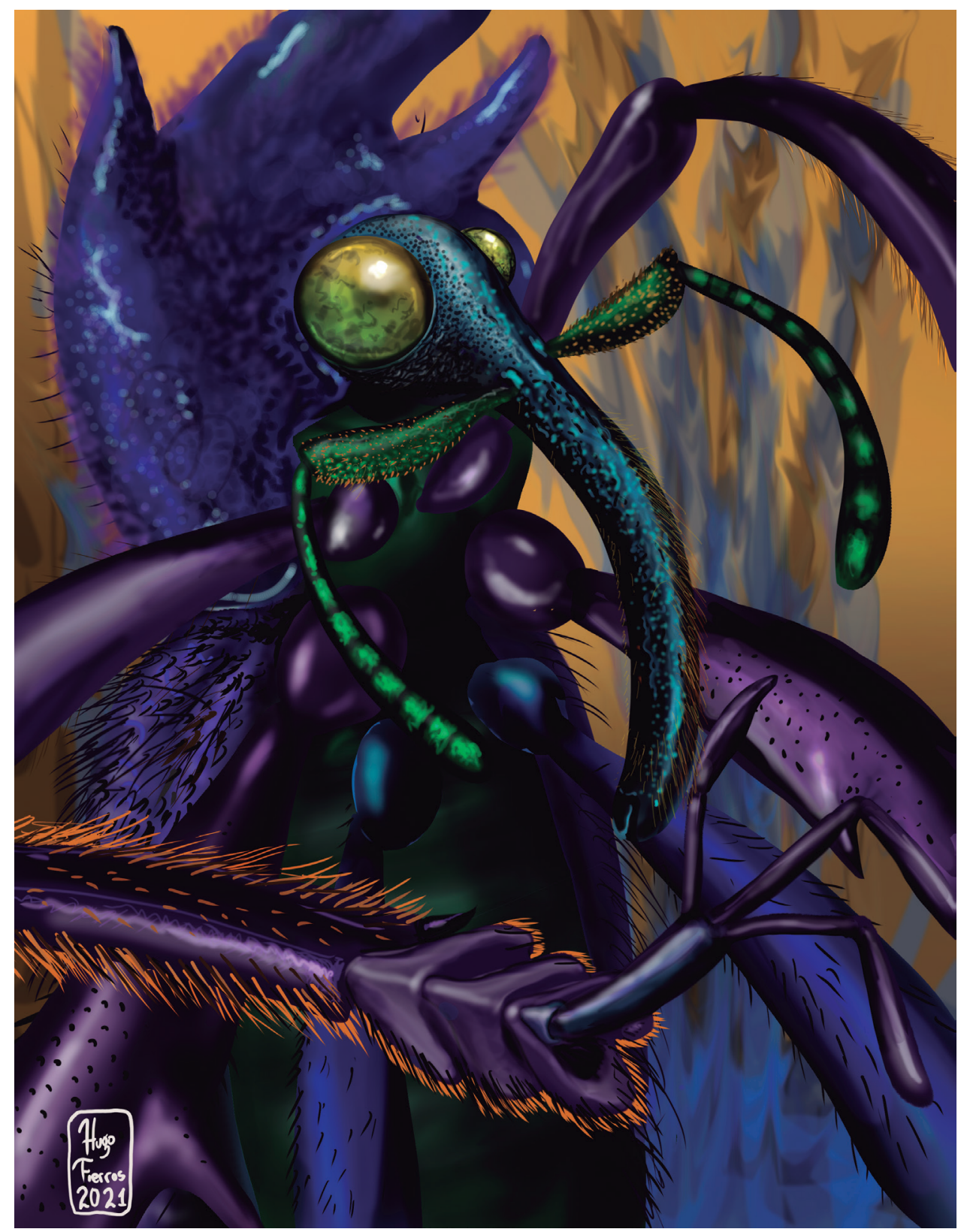

Dugesiana, Año 28, No. 2, (julio-diciembre, segundo semestre de 2021), es una publicación semestral, editada por la Universidad de Guadalajara, a través del Centro de Estudios en Zoología, por el Centro Universitario de Ciencias Biológicas y Agropecuarias. Camino Ramón Padilla Sánchez \# 2100, Nextipac, Zapopan, Jalisco, Tel. 37771150 ext. 33218, http://148.202.248.171/dugesiana/index.php/DUG/index, glenusmx@gmail.com. Editor responsable: José Luis Navarrete-Heredia. Reserva de Derechos al Uso Exclusivo 04-2009-062310115100-203, ISSN: 2007-9133, otorgados por el Instituto Nacional del Derecho de Autor. Responsable de la última actualización de este número: José Luis Navarrete-Heredia, Editor y Ana Laura González-Hernández, Asistente Editorial. Fecha de la última modificación 1 de julio de 2021, con un tiraje de un ejemplar.

Las opiniones expresadas por los autores no necesariamente reflejan la postura del editor de la publicación.

Queda estrictamente prohibida la reproducción total o parcial de los contenidos e imágenes de la publicación sin previa autorización de la Universidad de Guadalajara. 


\title{
A preliminary list of beetles (Insecta: Coleoptera) of forensic importance from Peru
}

\section{Lista preliminar de coleópteros (Insecta: Coleoptera) de importancia forense del Perú}

\author{
Alfredo Edgardo Giraldo-Mendoza \\ Museo de Entomología Klaus Raven Büller. Universidad Nacional Agraria La Molina. Av. La Molina \\ s/n. Apartado Postal 12-056. Lima, Perú. aegmendoza@gmail.com
}

\begin{abstract}
A preliminary list of beetles of forensic importance from Peru is presented, based on bibliographic revision. As a result, eight families, 31 genera, and 94 species are reported. According to their frequency in studies reviewed or number of species of forensic importance in each of them, families and genera that deserve special attention in Peru are Cleridae (Necrobia Olivier), Dermestidae (Dermestes Linnaeus), Histeridae (Hister Linnaeus, Euspilotus Lewis, Saprinus Erichson, Xerosaprinus Wenzel), Silphidae (Oxelytrum Gistel), Staphylinidae (Creophilus Leach, Philonthus Curtis) and Trogidae (Omorgus Erichson, Polynoncus Burmeister). These findings are discussed taking into account the available evidence from the Neotropical region.
\end{abstract}

Keywords: carcasses, Coleoptera, necrocolous species, Neotropical, South America.

\section{RESUMEN}

Se presenta una lista preliminar de coleópteros de importancia forense del Perú, basada en revisión bibliográfica. Como resultado, se reportan ocho familias, 31 géneros y 94 especies. Según su frecuencia en los estudios revisados o la cantidad de especies de importancia forense en cada uno de ellos, familias y géneros que merecen especial atención en Perú son Cleridae (Necrobia Olivier), Dermestidae (Dermestes Linnaeus), Histeridae (Hister Linnaeus, Euspilotus Lewis, Saprinus Erichson, Xerosaprinus Wenzel), Silphidae (Oxelytrum Gistel), Staphylinidae (Creophilus Leach, Philonthus Curtis) and Trogidae (Omorgus Erichson, Polynoncus Burmeister). Estos hallazgos son discutidos tomando en cuenta la evidencia disponible de la región Neotropical.

Palabras clave: cadáveres, Coleoptera, especies necrócolas, Neotrópico, Sudamérica.

Forensic entomology is a discipline of growing interest, as suggested by a review of studies on this subject published between 1984 and 2013 in a worldwide sample of scientific journals (Rodriguez-Olivares et al. 2015). Two other interesting trends revealed by this review were that pig is the most widely used biological model in cadaveric succession studies and, Coleoptera and Diptera are the most valuable forensic arthropod orders at family, genus and species level, due to its clear association with different stages of cadaveric succession.

The heterotrophic succession of animal remains is an ecological process necessary for the recycling of organic matter in the soil, in which various necrophagous, necrophilous and omnivorous species of Coleoptera arrive and inhabit carcasses during different stages of cadaveric decomposition (Nadeau et al. 2015, Zanetti et al. 2015a). In forensic entomology context, useful biological attributes of Coleoptera are long duration of its immature stages, which allows better estimates of the minimum postmortem interval (PMI min) and tough structures of larvae, pupae and exuviae, from which toxicological samples can be obtained (Midgley et al. 2010). According to studies carried out in Nearctic (Midgley et al. 2010, Nadeau et al. 2015), Neotropical (Almeida and Mise 2009, Almeida et al. 2015), Oriental (Bala and Singh 2015) and Palearctic (Özdemir and Sert 2009, Sawaby et al. 2016) regions, Coleoptera of forensic importance belong to following families: Anthicidae, Carabidae, Cleridae, Dermestidae, Geotrupidae, Histeridae, Hybosoridae, Hydrophilidae, Lathridiidae, Leiodidae, Monotomidae, Nitidulidae, Ptinidae, Scarabaeidae, Silphidae, Staphylinidae, Tenebrionidae and Trogidae.

In Peru, forensic entomology has also received increasing attention in recent years. Thus, there are a number of studies on cadaveric succession available in scientific journals or as dissertation works. Most of them were carried out in localities to the west of the Peruvian Andes including Callao (Iannacone 2003), La Libertad (Sarmiento-Yengle and Padilla-Sagástegui 2015), Lambayeque (Ginés-Carrillo et al. 2015, Medina-Achín et al. 2018), Lima (PecerosPeláez 2011, Grados 2014, Murrugarra-Bringas 2016) and Piura (Andrade-Herrera et al. 2018). In comparison, the number of studies is rather scarce in the eastern Amazon (Pizango-Pérez et al. 2019) or practically absent for localities in inter-Andean valleys and high Andean plateaus.

The present work provides a preliminary list of beetles of forensic importance from Peru, based on an extensive bibliographic review, including studies on entomological cadaveric succession, reviews of forensic relevant species, checklists for Peruvian fauna and others works with valuable data for necrocolous beetle species. This list is ex- 
pected to be a useful source of information for future field surveys and cadaver succession studies in Peru.

\section{MATERIAL AND METHODS}

The list of genera and species was prepared from a bibliographic review of works dealing with Neotropical necrocolous beetles, following five stages:

First, 35 recent studies (1997-2019) describing the cadaveric succession of insects in different localities of South American countries, were used to elaborate the basic list of beetle species. These studies were selected by a combination of three criteria, availability in electronic databases, recent publication date and representation of different environmental conditions found in South America. Studies carried out in Argentina (7), Bolivia (1), Brazil (9), Colombia (4), Ecuador (1), Peru (9), Uruguay (2) and Venezuela (2) were included, which are detailed in appendix 1.

Second, data from the basic list of species were grouped into genera, to find the most frequent genera of necrocolous beetles. Thus, only species of genera with frequency above mean (0.09) in a range of 0.03-0.80 were used in the following stages. For each genus, frequency $=[$ number of genus records] / [total number of studies].

Third, eight reviews on beetles of forensic importance were used to check and expand South American species in most frequent genera selected in second stage. The included studies cover beetle fauna of Argentina (Oliva 2001, Aballay et al. 2013, 2014), Brazil (Vasconcelos and Araujo 2012, Almeida et al. 2015, Celli et al. 2015), Ecuador (Salazar y Donoso 2015) and Latin America (Almeida and Mise 2009).

Fourth, seven recent checklists were used to check the species recorded for most frequent genera in Peru. The included studies are about Cleridae (Burke and Chaboo 2015), Dermestidae (Háva and Chaboo 2015), Histeridae (Mazur 2011, Arriagada 2015, Tishechkin and Dégallier 2015), Nitidulidae (Cline et al. 2015), Scarabaeoidea (Ratcliffe et al. 2015), Silphidae (Giraldo-Mendoza 2016) and Staphylinidae (Newton 2015).

Fifth, 10 recent works with biology remarks or collecting data for most frequent genera were used for to add species overlooked by studies cited in first and third stages. The included studies are about Deltochilum Eschscholtz (González et al. 2009), Eurysternus Dalman (Génier 2009), Euspilotus Lewis (Dégallier et al. 2012, Arriagada 2015), Phelister Marseul (Caterino and Tishechkin 2019, 2020), Scarabaeinae (Ratcliffe 2013, Cajaiba et al. 2017), Trogidae (Scholtz 1990) and Xanthopygus Kraatz (Navarrete-Heredia 2004).

The species obtained with the procedure described above were classified into three categories:

Known species, species recorded in the nine entomological cadaveric succession studies carried out in Peruvian localities included in first stage. Also, their forensic importance is supported by cadaveric succession studies and reviews carried out in other South American countries included in first and third stages.

Expected species, species not recorded yet in cadaveric succession trials carried out in Peruvian territory. Their forensic importance is supported by cadaveric succession studies and reviews carried out in other South American countries included in first and third stages.

Potential species, species not recorded yet in cadaveric succession trials carried out in South American countries. They are likely forensic valuables based on collecting data indicating its association with vertebrate carcasses or catch with carrion-baited traps as noted by the studies of fifth stage.

In addition to the information at the species level, for each genus were calculated: a simple ratio of forensic important species $=[$ forensic important species] $/$ [species recorded in Peru] and an index of forensic importance $=$ $[(0.5)$ (known species) $+(0.3)$ (expected species $)+(0.2)$ (potential species)] / [species recorded in Peru]. Both equations were elaborated intuitively and proposed here, as quantitative expressions to highlight forensic importance of selected genera.

Taxonomic determination carried out in Peruvian cadaveric succession studies could not be checked for the most part. Two clear exceptions were the studies carried out by Grados (2014) and Murrugarra-Bringas (2016), whose specimens are housed in Museo de Entomología Klaus Raven Büller - Universidad Nacional Agraria La Molina, Lima, Peru (MEKRB). Also, some species of Histeridae could be identified from the photos presented by Ginés-Carrillo et al. (2015) and Medina-Achín et al. (2018). Based on currently knowledge of Peruvian Histeridae fauna, the record of Saprinus aeneus (Fabricius) (Iannacone 2003), species that present known distribution to England, Europe, Russia, Syria, Turkey, Iran and, Kazakhstan (Mazur 2011), was attributed to an indeterminate species of the genus $\mathrm{Eu}$ spilotus.

\section{RESULTS AND DISCUSSION}

The present list of beetles of forensic importance includes eight families, 31 genera, and 94 species. The most frequent genera in the 35 studies of cadaveric succession were Dermestes Linnaeus (0.80), Necrobia Olivier (0.71) and Euspilotus (0.63) recorded in more than half of studies and Hister Linnaeus (0.46), Philonthus Curtis (0.43) and Oxelytrum Gistel (0.40) recorded in more than a third of studies. The genera Aleochara Gravenhorst, Eurysternus, Hister, Phelister, Philonthus, Polynoncus and Stelidota Erichson were recorded in Peruvian cadaveric succession studies, but only as undetermined species. For the genera Atheta Thomson, Anotylus Thomson and Canthidium Erichson, it was not possible to assign forensic valuable species for the Peruvian fauna.

The species included in each category were 14 known, 
53 expected and 27 potential. The genera with the highest ratio and index of forensic importance species were: Creophilus Leach, Dermestes, Euspilotus, Necrobia, Omorgus Erichson, Oxelytrum, Polynoncus, Saprinus Erichson and Xerosaprinus Wenzel. Data for each of 31 genera are presented in appendix 2.

In the list, species are arranged according to forensic importance categories established in material and methods section, known, expected or potential.

\section{Known species}

Species recorded in entomological cadaveric succession studies carried out in Peru and other South American countries. Detailed Peruvian records and South American country records are provided.

Cleridae Latreille, 1802

Korynetinae Laporte, 1836

Necrobia Olivier, 1795

Necrobia ruficollis (Fabricius, 1775)

PERU: Lima, Lima, Pantanos de Villa, pig carcasses (Murrugarra-Bringas 2016). ARGENTINA (Oliva 2001, Centeno et al. 2002, Aballay et al. 2017), BRAZIL (Mise et al. 2007, Souza et al. 2008), URUGUAY (Remedios-De León et al. 2017, Castro et al. 2019).

\section{Necrobia rufipes (DeGeer, 1775)}

PERU: Callao, Ventanilla, pig carcasses (Iannacone 2003); La Libertad, Trujillo, rabbit carcasses (Sarmiento-Yengle and Padilla-Sagástegui 2015); Lambayeque, Lambayeque, UNPRG, pig carcasses (Ginés-Carrillo et al. 2015, Medina-Achín et al. 2018); Lima, Huarochirí, pig carcasses (Peceros-Peláez 2011), Lima, El Agustino, pig carcasses (Grados 2014), Pantanos de Villa, pig carcasses (Murrugarra-Bringas 2016); Piura, Piura, Castilla, guinea pig carcasses (Andrade-Herrera et al. 2018). ARGENTINA (Oliva 2001, Centeno et al. 2002, Aballay et al. 2008, Aballay et al. 2012, Trigo and Centeno 2014, Armani et al. 2015, Aballay et al. 2017, Armani et al. 2017), BRAZIL (Souza and Linhares 1997, Mise et al. 2007, Souza et al. 2008, Silva and Santos 2012, Santos et al. 2014), COLOMBIA (Wolff et al. 2001), ECUADOR (Aguirre-Carrera 2014), URUGUAY (Remedios-De León et al. 2017, Castro et al. 2019), VENEZUELA (Magaña et al. 2006).

Dermestidae Latreille, 1804

Dermestinae Latreille, 1804

Dermestes Linnaeus, 1758

Dermestes ater DeGeer, 1774

PERU: Lima, Huarochirí, pig carcasses (Peceros-Peláez 2011); Piura, Piura, Castilla, guinea pig carcasses (Andrade-Herrera et al. 2018). ARGENTINA (Centeno et al. 2002, Aballay et al. 2008, Aballay et al. 2012), VENEZUELA (Liria-Salazar 2006, Magaña et al. 2006).
Dermestes frischii Kugelann, 1792

PERU: Lambayeque, Lambayeque, UNPRG, pig carcasses (Ginés-Carrillo et al. 2015); La Libertad, Trujillo, rabbit carcasses (Sarmiento-Yengle and Padilla-Sagástegui 2015); Lima, Huarochirí, pig carcasses (Peceros-Peláez 2011), Lima, El Agustino, pig carcasses (Grados 2014), Pantanos de Villa, pig carcasses (Murrugarra-Bringas 2016); Piura, Piura, Castilla, guinea pig carcasses (Andrade-Herrera et al. 2018). VENEZUELA (Magaña et al. 2006).

\section{Dermestes maculatus DeGeer, 1774}

PERU: Callao, Ventanilla, pig carcasses (Iannacone 2003); Lambayeque, Lambayeque, UNPRG, pig carcasses (Ginés-Carrillo et al. 2015, Medina-Achín et al. 2018); Lima, Huarochirí, pig carcasses (Peceros-Peláez 2011), Lima, Pantanos de Villa, pig carcasses (Murrugarra-Bringas 2016); Loreto, Maynas, pig carcasses (Pizango-Pérez et al. 2019); Piura, Piura, Castilla, guinea pig carcasses (Andrade-Herrera et al. 2018). ARGENTINA (Oliva 2001, Centeno et al. 2002, Aballay et al. 2008, Aballay et al. 2012, Trigo and Centeno 2014, Armani et al. 2015, Aballay et al. 2017, Armani et al. 2017), BRAZIL (Souza and Linhares 1997, Mise et al. 2007, Souza et al. 2008, Santos et al. 2014, Costa-Silva et al. 2017), ECUADOR (Aguirre-Carrera 2014), URUGUAY (Remedios-De León et al. 2017, Castro et al. 2019).

Histeridae Gyllenhal, 1808

Saprininae Blanchard, 1845

Euspilotus Lewis, 1907

Euspilotus ater Arriagada, 2015

PERU: Lima, Lima, El Agustino, pig carcasses (Grados 2014).

Euspilotus (Euspilotus) decoratus (Erichson, 1834)

PERU: Lambayeque, Lambayeque, UNPRG, pig carcasses (Ginés-Carrillo et al. 2015, Medina-Achín et al. 2018); Lima, Lima, El Agustino, pig carcasses (Grados 2014), Pantanos de Villa, pig carcasses (Murrugarra-Bringas 2016).

Saprinus Erichson, 1834

Saprinus caerulescens (Hoffmann, 1803)

PERU: Lambayeque, Lambayeque, UNPRG, pig carcasses (Ginés-Carrillo et al. 2015, Medina-Achín et al. 2018); Lima, Lima, El Agustino, pig carcasses (Grados 2014), Pantanos de Villa, pig carcasses (Murrugarra-Bringas 2016); Piura, Piura, Castilla, guinea pig carcasses (Andrade-Herrera et al. 2018).

Xerosaprinus Wenzel, 1962

Xerosaprinus (Xerosaprinus) chiliensis (Marseul, 1855)

PERU: Lima, Lima, El Agustino, pig carcasses (Grados 2014), Pantanos de Villa, pig carcasses (Murrugarra-Bringas 2016). 
Scarabaeidae Latreille, 1802

Scarabaeinae Latreille, 1802

Canthon Hoffmannsegg, 1817

Canthon balteatus Boheman, 1858

PERU: Piura, Piura, Castilla, guinea pig carcasses (Andrade-Herrera et al. 2018).

Canthon fuscipes Erichson, 1847

PERU: Piura, Piura, Castilla, guinea pig carcasses (Andrade-Herrera et al. 2018).

Canthon subhyalinus Harold, 1867

PERU: Loreto, Maynas, pig carcasses (Pizango-Pérez et al. 2019).

Silphidae Latreille, 1807

Silphinae Latreille, 1807

Oxelytrum Gistel, 1848

Oxelytrum cayennense (Sturm, 1826)

PERU: Loreto, Maynas, pig carcasses (Pizango-Pérez et al. 2019). BRAZIL (Mise et al. 2010), COLOMBIA (Ramos-Pastrana et al. 2018), ECUADOR (Aguirre-Carrera 2014).

Trogidae MacLeay, 1819

Omorgus Erichson, 1847

Omorgus suberosus (Fabricius, 1775)

PERU: Piura, Piura, Castilla, guinea pig carcasses (Andrade-Herrera et al. 2018). ARGENTINA (Aballay et al. 2008, Aballay et al. 2012, Aballay et al. 2017), BRAZIL (Santos et al. 2014, Costa-Silva et al. 2017), URUGUAY (Castro et al. 2019), VENEZUELA (Magaña et al. 2006).

\section{Expected species}

Species recorded in cadaveric succession studies and reviews carried out in South American countries, but not yet in Peru. South American country records are provided.

Dermestidae Latreille, 1804

Dermestinae Latreille, 1804

Dermestes carnivorus Fabricius, 1775

ECUADOR (Aguirre-Carrera 2014).

Dermestes haemorrhoidalis Küster, 1852

BRAZIL (Santos et al. 2014).

Dermestes peruvianus Laporte, 1840

ARGENTINA (Oliva 2001), BRAZIL (Souza and Linhares 1997).

Histeridae Gyllenhal, 1808

Histerinae Gyllenhal, 1808

Hister Linnaeus, 1758

Hister cavifrons Marseul, 1854

BRAZIL (Celli et al. 2015, Costa-Silva et al. 2017).
Omalodes Dejean, 1834

Omalodes bifoveolatus Marseul, 1853

BRAZIL (Mise et al. 2010, Vasconcelos and Araujo 2012, Celli et al. 2015,).

Omalodes foveola Erichson, 1834

BRAZIL (Mise et al. 2010, Santos et al. 2014, Celli et al. 2015, Costa-Silva et al. 2017).

Omalodes lucidus Erichson, 1834

BRAZIL (Mise et al. 2010, Celli et al. 2015). Note: Peruvian records refer to Omalodes lucidus peruvianus Marseul, 1861

Phelister Marseul, 1853

Phelister rufinotus Marseul, 1861

ARGENTINA (Aballay et al. 2013), URUGUAY (Remedios-De León et al. 2017).

Saprininae Blanchard, 1845

Euspilotus Lewis, 1907

Euspilotus (Euspilotus) lepidus (Erichson, 1847)

ARGENTINA (Aballay et al. 2013, Aballay et al. 2017).

Euspilotus (Hesperosaprinus) azureus Sahlberg, 1823

ARGENTINA (Aballay et al. 2013), BRAZIL (Souza and Linhares1997, Mise et al. 2007, Souza et al. 2008, Mise et al. 2010, Silva and Santos 2012, Santos et al. 2014, Celli et al. 2015, Costa-Silva et al. 2017), ECUADOR (Aguirre-Carrera 2014), URUGUAY (Remedios-De León et al. 2017, Castro et al. 2019).

Euspilotus (Hesperosaprinus) modestus (Erichson, 1834)

ARGENTINA (Aballay et al. 2008, Aballay et al. 2012, Aballay et al. 2013, Armani et al. 2015, Aballay et al. 2017, Armani et al. 2017), URUGUAY (Remedios-De León et al. 2017, Castro et al. 2019).

Euspilotus (Hesperosaprinus) pavidus (Erichson, 1834)

ARGENTINA (Aballay et al. 2008, Aballay et al. 2012, Aballay et al. 2013, Aballay et al. 2017).

Xerosaprinus Wenzel, 1962

Xerosaprinus (Xerosaprinus) diptychus (Marseul, 1855)

ARGENTINA (Aballay et al. 2008, Aballay et al. 2012, Aballay et al. 2013, Aballay et al. 2017), BRAZIL (Santos et al. 2014).

Nitidulidae Latreille, 1802

Carpophilinae Erichson, 1842

Carpophilus Stephens, 1830

Carpophilus hemipterus Linnaeus, 1758

ARGENTINA (Oliva 2001). 
Nitidulinae Latreille, 1802

Stelidota Erichson, 1843

Stelidota geminata (Say, 1825)

BRAZIL (Santos et al. 2014).

Scarabaeidae Latreille, 1802

Aphodiinae Leach, 1815

Ataenius Harold 1867

Ataenius picinus Harold, 1868

BRAZIL (Mise et al. 2007, Costa-Silva et al. 2017).

Scarabaeinae Latreille, 1802

Canthon Hoffmannsegg, 1817

Canthon conformis Harold, 1868

BRAZIL (Almeida and Mise 2009, Costa-Silva et al. 2017).

Canthon lituratus (Germar, 1813)

BRAZIL (Almeida and Mise 2009, Almeida et al. 2015).

Canthon mutabilis Lucas, 1857

BRAZIL (Almeida and Mise 2009, Almeida et al. 2015).

Canthon muticus Harold, 1867

BRAZIL (Almeida and Mise 2009, Almeida et al. 2015).

Canthon septemmaculatus (Latreille, 1807)

BRAZIL (Almeida and Mise 2009, Almeida et al. 2015).

Canthon smaragdulus (Fabricius, 1781)

BRAZIL (Almeida and Mise 2009, Almeida et al. 2015).

Canthon triangularis Drury, 1870

BRAZIL (Almeida and Mise 2009, Mise et al. 2010).

Canthon unicolor Blanchard, 1843

BRAZIL (Almeida et al. 2015).

Coprophanaeus Olsoufieff, 1924

Coprophanaeus (Megaphanaeus) lancifer (Linnaeus, 1767)

BRAZIL (Mise et al. 2010).

Deltochilum Eschscholtz, 1822

Deltochilum (Calhyboma) carinatum Westwood, 1837

BRAZIL (Almeida and Mise 2009, Almeida et al. 2015).

Deltochilum (Calhyboma) robustus Molano and Gonzalez, 2009

ECUADOR (Aguirre-Carrera 2014).
Deltochilum (Deltohyboma) peruanum Paulian, 1939

BRAZIL (Mise et al. 2010).

Deltochilum (Telhyboma) orbiculare Lansberge, 1874

BRAZIL (Almeida and Mise 2009, Almeida et al. 2015).

Dichotomius Hope, 1838

Dichotomius (Cephagonus) fissus (Harold, 1867)

BRAZIL (Almeida et al. 2015).

Dichotomius (Dichotomius) semiaeneus (Germar, 1824)

BRAZIL (Almeida et al. 2015).

Eurysternus Dalman, 1824

Eurysternus caribaeus (Herbst, 1789)

BRAZIL (Costa-Silva et al. 2017).

Eurysternus foedus Guérin-Méneville, 1830

BRAZIL (Almeida and Mise 2009, Almeida et al. 2015).

Eurysternus hypocrita Balthasar, 1939

BRAZIL (Mise et al. 2010).

Ontherus Erichson, 1847

Ontherus (Ontherus) sulcator (Fabricius, 1775)

BRAZIL (Costa-Silva et al. 2017), URUGUAY (Castro et al. 2019).

Onthophagus Latreille, 1807

Onthophagus bidentatus Drapiez, 1819

BRAZIL (Almeida and Mise 2009, Almeida et al. 2015).

Silphidae Latreille, 1807

Silphinae Latreille, 1807

Oxelytrum Gistel, 1848

Oxelytrum anticola (Guérin-Méneville, 1855)

ECUADOR (Aguirre-Carrera 2014).

Oxelytrum discicolle (Brullé, 1840)

BRAZIL (Mise et al. 2007, Souza et al. 2008, Costa-Silva et al. 2017), COLOMBIA (Ospina-Maldonado 2006, Grisales et al. 2010), ECUADOR (Aguirre-Carrera 2014), URUGUAY (Remedios-De León et al. 2017).

Staphylinidae Latreille, 1802

Aleocharinae Fleming, 1821

Aleochara Gravenhorst, 1802

Aleochara (Coprochara) notula Erichson, 1839

BRAZIL (Almeida et al. 2015). 
Aleochara (Coprochara) signaticollis Fairmaire \& Germain, 1862

ARGENTINA (Aballay et al. 2014).

Aleochara (Xenochara) puberula Klug, 1832

ARGENTINA (Aballay et al. 2014).

Aleochara (Xenochara) taeniata Erichson, 1839

BRAZIL (Almeida et al. 2015).

Staphylininae Latreille, 1802

Belonuchus Nordmann, 1837

Belonuchus rufipennis (Fabricius, 1801)

ARGENTINA (Aballay et al. 2014).

Creophilus Leach, 1819

Creophilus maxillosus (Linnaeus, 1758)

ARGENTINA (Centeno et al. 2002, Aballay et al. 2008, Aballay et al. 2012, Armani et al. 2015, Armani et al. 2017), BOLIVIA (Castillo et al. 2017), URUGUAY (Remedios-De León et al. 2017).

Creophilus variegatus Mannerheim, 1830

ARGENTINA (Aballay et al. 2014), BRAZIL (Costa-Silva et al. 2017).

Eulissus Mannerheim, 1830

Eulissus chalybaeus Mannerheim, 1830

ARGENTINA (Aballay et al. 2014), BRAZIL (Souza and Linhares 1997, Mise et al. 2007, Moretti et al. 2008, Costa-Silva et al. 2017), ECUADOR (Aguirre-Carrera 2014).

Philonthus Curtis, 1829

Philonthus feralis Erichson, 1840

BRAZIL (Almeida et al. 2015).

Philonthus figulus Erichson, 1840

BRAZIL (Santos et al. 2014).

Philonthus flavolimbatus Erichson, 1840

BRAZIL (Almeida et al. 2015).

Philonthus longicornis Stephens, 1832

ARGENTINA (Aballay et al. 2008, Aballay et al. 2012).

Platydracus Thomson, 1858

Platydracus chrysotrichopterus (Scheerpeltz, 1933)

ARGENTINA (Aballay et al. 2014).

Platydracus ochropygus (Nordmann, 1837)

BRAZIL (Mise et al. 2010, Costa-Silva et al. 2017).

Platydracus scabrosus (Curtis, 1839)

ARGENTINA (Aballay et al. 2014).

\section{Potential species}

Species not recorded yet in cadaveric succession trials carried out in South American countries. Their forensic importance is based on collecting data indicating its association with vertebrate carcasses or catch with carrion-baited traps.

Histeridae Gyllenhal, 1808

Histerinae Gyllenhal, 1808

Phelister Marseul, 1853

Phelister blairi Hinton, 1935

Phelister sphaericus Caterino \& Tishechkin, 2020

Phelister uncinatus Caterino \& Tishechkin, 2020

Saprininae Blanchard, 1845

Euspilotus Lewis, 1907

Euspilotus (Hesperosaprinus) amazonicus (Desbordes, 1923)

Euspilotus (Hesperosaprinus) arrogans (Marseul, 1855)

Euspilotus (Hesperosaprinus) excavata Arriagada, 2012

Euspilotus (Hesperosaprinus) flaviclava (Marseul, 1870)

Scarabaeidae Latreille, 1802

Scarabaeinae Latreille, 1802

Coprophanaeus Olsoufieff, 1924

Coprophanaeus (Coprophanaeus) parvulus (Olsoufieff, 1924)

Coprophanaeus (Coprophanaeus) telamon (Erichson, 1847)

Deltochilum Eschscholtz, 1822

Deltochilum (Calhyboma) hypponum Buquet, 1844

Deltochilum (Calhyboma) mexicanum Burmeister, 1848

Deltochilum (Hybomidium) amazonicum Bates, 1887

Dichotomius Hope, 1838

Dichotomius (Dichotomius) worontzowi (Pereira, 1942)

Dichotomius (Luederwaldtinia) lucasi (Harold, 1869)

Eurysternus Dalman, 1824

Eurysternus cayennensis Laporte, 1840

Eurysternus hamaticollis Balthasar, 1939

Eurysternus plebejus Harold, 1880

Eurysternus wittmerorum Martínez, 1988

Onthophagus Latreille, 1807

Onthophagus clypeatus Blanchard, 1846

Staphylinidae Latreille, 1802

Staphylininae Latreille, 1802

Xanthopygus Kraatz, 1857

Xanthopygus xanthopygus (Nordmann, 1837)

Trogidae MacLeay, 1819

Omorgus Erichson, 1847

Omorgus persuberosus (Vaurie, 1962) 
Polynoncus Burmeister, 1876

Polynoncus aricensis (Gutiérrez, 1950)

Polynoncus brevicollis (Eschscholtz, 1822)

Polynoncus gordoni (Steiner, 1981)

Polynoncus peruanus (Erichson, 1847)

Polynoncus pilularius (Germar, 1824)

Polynoncus sallei (Harold, 1872)

According to frequency in studies reviewed and forensic importance ratios presented here, Dermestes and Necrobia genera are the most relevant beetles of forensic importance in Peru and elsewhere. Recently, it has been shown that the species of these genera leave significant traces on carcasses, marks on epithelial and connective tissues caused by feeding activity of Necrobia rufipes (DeGeer, 1775) (Zanetti et al. 2015b), and bone depressions caused by feeding and pupation of Dermestes maculatus DeGeer, 1774 (Zanetti et al. 2018). The identification of these species is relatively simple, with valid keys for wide geographic areas, since the species of these genera are cosmopolitan and, in many cases, also pests of stored products (Midgley et al. 2010).

Forensic importance ratios for Histeridae genera attained their highest values for Euspilotus, Saprinus and $\mathrm{Xe}$ rosaprinus, all of them belonging to Saprininae subfamily. Species of Euspilotus and Xerosaprinus have been frequently associated with vertebrate carcasses in arid and tropical ecosystems of South America (Dégallier et al. 2012, Aballay et al. 2013, Arriagada 2015, Celli et al. 2015). Saprinus caerulescens (Hoffmann, 1803) is an introduced and established species in Peru (Arriagada 2015), well known for its necrophilous habits in countries of the Palearctic region (Özdemir and Sert 2009, Sawaby et al. 2016). In comparison, forensic value of species in the Histerinae subfamily appears rather lesser. The patterns observed here for Peruvian fauna of necrophilous histerids reflect the global patterns observed in studies published from 1811 to 2014 for this group (Correa et al. 2020). In this review, subfamilies recorded with the highest frequency were Saprininae $(62 \%)$ and Histerinae (30\%), and among the genera with highest percentage of necrophilous species were Euspilotus (29\%), Saprinus (36\%) and Xerosaprinus (21\%). Although there are genera and species widely distributed in South America, available keys for Argentina (Aballay et al. 2013) and Brazil (Celli et al. 2015) should be applied with caution to avoid misidentifications.

Within Staphylinidae, forensic importance ratios were highest for Creophilus genus, of which C. maxillosus (Linnaeus, 1758) is a cosmopolitan species with well-established necrophilous habits (Navarrete-Heredia et al. 2002, Asenjo and Clarke 2007). Other Staphylininae genera did not attain high values in calculated ratios, but they have species with Pan American distributions and have been clearly associated with animal carcasses or collected with carrion-baited traps, this is the case of Belonuchus rufipennis (Fabricius, 1801), Eulissus chalybeus Mannerheim, 1830 and Xanthopygus xanthopygus (Nordmann, 1837)
(Navarrete-Heredia et al. 2002, Navarrete-Heredia 2004). In comparison, there is considerable uncertainty about the forensic value of species in other genera of Staphylininae, and for Aleocharinae and Oxytelinae subfamilies. Although there are genera and species widely distributed in America, available keys for Argentina (Aballay et al. 2014) and Mexico (Navarrete-Heredia et al. 2002) should be applied with caution to avoid misidentifications.

In Silphidae and Trogidae families, all species are clearly associated with carrion, being necrophilous and necrophagous respectively. The forensic importance for genus Oxelytrum was noted early by Oliva (2001) and the same is suggested by ratios presented here. This statement has been corroborated by cadaveric succession trials and findings on human corpses for $O$. discicolle (Brullé, 1840) and $O$. cayennense (Sturm, 1826), whose larvae and adult have potential use as a postmortem interval indicator because have been recorded on carcasses from early days onward (Ururahy-Rodrigues et al. 2010, Kotzko et al. 2015). In the case of $O$. anticola (Guérin-Méneville, 1855), it was included in a checklist of forensic valuable species from Ecuador (Salazar y Donoso 2015) and should be forensically important in Peruvian Andean environments where other silphids are scarce or absent (Giraldo-Mendoza 2016). Within Trogidae, Omorgus and Polynoncus reached high values for forensic importance ratios that were proposed. Omorgus suberosus (Fabricius, 1775) has the greatest forensic potential due to its wide distribution from Canada to southern Argentina, and its probable tolerance to anthropogenic environments (Scholtz 1990, Correa et al. 2013). While other trogid species with a more restricted distribution, endemic or inhabiting native vegetation require further studies.

In Nitidulidae and Scarabaeidae (Aphodiinae, Scarabaeinae) families, most species are associated to decaying fruits and dung respectively. Consequently, more rigorous studies are required to establish preference or specialization for carrion. For Scarabaeinae, studies incorporating simultaneous collecting with different baits (carrion, dung, rotting fruits) and establishing their food preferences (relative abundance per bait) are required, like those performed by Ratcliffe (2013) and Cajaiba et al. (2017). The forensic importance of Ataenius picinus Harold, 1868 has been suggested from cadaveric succession trials in which its abundance was higher during decomposition phase and positively related to duration for each stage (Ries et al. 2016). Similarly, Coprophanaeus lancifer (Linnaeus, 1767) has been suggested as a biotaphonomic important species, with the ability to dismember and to change position of a man-size pig carcass (Ururahy-Rodrigues et al. 2008).

Several species, genera and even families of necrocolous beetles that occur in Peru would have been omitted from present list, since only the most frequent ones were included and due to the lack of studies about carrion-associated insects in Peruvian localities. The families relevant to the Neotropics, but absent from the list are Carabidae, Leiodidae, Geotrupidae, Hybosoridae, Hydrophilidae, 
Monotomidae and Tenebrionidae (Almeida and Mise 2009, Almeida et al. 2015). Regarding Carabidae and Tenebrionidae, most are epigeic species effectively sampled with pitfall traps (Zanetti et al. 2016) and in some ecosystems they could be important components of the necrocolous fauna. For instance, carabids collected with pitfall traps surrounding pig carcasses in an agroecosystem of Buenos Aires province (Scampini et al. 2002) and tenebrionids collected with carrion-baited traps and on vertebrate carcasses in arid and semiarid areas of Buenos Aires, Catamarca, Mendoza and San Juan provinces (Aballay et al. 2016).

Putting the future of forensic entomology in Peru in perspective, a first point is to break the bias that until now has had the geographic location of cadaveric succession studies (Appendix 1). More studies of this type need to be carried out in inter-Andean valleys, high Andean plateaus and eastern Amazon. A second point is using combinations of sampling methods rather than a single method in cadaveric succession studies. Manual collecting is the most widely method employed, but use of Malaise traps, pitfall traps, Shannon traps, substrate extraction, and underneath trays are advisable for to collect more taxa (Zanetti et al. 2016, Santos et al. 2019, Appendix 1). A third point is to carry out surveys of necrocolous beetles covering wider geographic areas, examining vertebrate carcasses found in open air and using carrion-baited traps as has been successfully applied in other countries, such as Argentina (Aballay et al. 2013, 2014, 2016) and Mexico (Navarrete-Heredia et al. 2002, Rodriguez-Olivares et al. 2015).

\section{ACKNOWLEDGMENTS}

The study of insects of forensic importance at MEKRB was started and promoted by Javier Huanca. To Chilean entomologist Gerardo Arriagada for taxonomic determination and donation of type specimens that improved Saprininae collection at MEKRB.

\section{LITERATURE CITED}

Aballay, F.H., G. Arriagada, G.E. Flores and N.D. Centeno. 2013. An illustrated key to and diagnoses of the species of Histeridae (Coleoptera) associated with decaying carcasses in Argentina. ZooKeys, 261: 61-84.

Aballay, F.H., M.R. Chani-Posse, M.R. Ayón, M.B. Maldonado and N.D. Centeno. 2014. An illustrated key to and diagnoses of the species of Staphylinidae (Coleoptera) associated with decaying carcasses in Argentina. Zootaxa, 3860 (2): 101-124.

Aballay, F.H., G.E. Flores, V.A. Silvestro, N.I. Zanetti and N.D. Centeno. 2016. An illustrated key to, and diagnoses of the species of Tenebrionidae (Coleoptera) associated with decaying carcasses in Argentina. Annales Zoologici, 66(4):703-726.

Aballay, F.H., A.F. Murúa, J.C. Acosta y N. Centeno. 2008. Primer registro de artropodofauna cadavérica en sustratos humanos y animales en San Juan, Argentina. Revista de la Sociedad Entomológica Argentina, 67(3-4): 157-
163.

Aballay, F.H., A.F. Murúa, J.C. Acosta and N. Centeno. 2012. Succession of carrion fauna in the arid region of San Juan Province, Argentina and its forensic relevance. Neotropical Entomology, (41): 27-31.

Aballay, F.H., F.N. Jofré y N.D. Centeno. 2017. Asociación y estratificación de la entomofauna cadavérica a diferentes profundidades en el suelo como indicadores complementarios en largos intervalos post mortem. Revista del Museo Argentino de Ciencias Naturales n.s., 19(2): 225-234.

Aguirre-Carrera, S.J. 2014. Línea base de insectos de importancia forense en diferentes zonas climáticas de Pichincha, Ecuador. Tesis de Licenciatura, Pontifica Universidad Católica del Ecuador, Quito.

Almeida, L.M., R.C. Corrêa and P.C. Grossi. 2015. Coleoptera species of forensic importance from Brazil: an updated list. Revista Brasileira de Entomologia, (59): 274-284.

Almeida, L.M. and K.M. Mise. 2009. Diagnosis and key of the main families and species of South American Coleoptera of forensic importance. Revista Brasileira de Entomologia, 53(2): 227-244.

Andrade-Herrera, K., C. Ruiz-González y M. Córdova-Espinoza. 2018. Estudio comparativo de insectos asociados a cadáveres de cobayas en dos formas de muerte en Castilla, Piura (Perú). Cuadernos de Medicina Forense, 24(1-2): 6-13.

Armani, A.P., N.D. Centeno y S.L. Dahinten. 2015. Primer estudio de artropodofauna cadavérica sobre modelos experimentales porcinos en el noreste de la provincia del Chubut, Argentina. Revista de la Sociedad Entomológica Argentina, 74 (3-4): 123-132.

Armani, A.P., S. Dahinten y N. Centeno. 2017. Artropodofauna cadavérica asociada a cerdo doméstico (Sus scrofa) en un ambiente ribereño en Chubut, Argentina. Revista Colombiana de Entomología, 43(2): 262-267.

Arriagada, G. 2015. Nueva especie de Saprininae de Perú, Chile y Argentina, nuevos registros y sinonimias (Coleoptera: Histeridae). Boletín del Museo Nacional de Historia Natural, Chile, 64: 181-197.

Asenjo, A. and D.J. Clarke. 2007. First record of Creophilus maxillosus (Linnaeus, 1758) (Staphylinidae) for Peru. The Coleopterists Bulletin, 61(4):551.

Bala, M. and N. Singh. 2015. Beetles and forensic entomology: A comprehensive review. Journal of Entomological Research, 39 (4): 293-302.

Burke, A. and C.S. Chaboo. 2015. Beetles (Coleoptera) of Peru: A survey of the families. Cleridae Latreille, 1802. Journal of the Kansas Entomological Society, 88(2): 260-266.

Cajaiba, R.L., E. Périco, W.B. da Silva and M. Santos. 2017. Attraction of Scarabaeinae (Coleoptera: Scarabaeidae) to different baits in the Brazilian Amazon region. Revista de Biología Tropical, 65(3): 917-924.

Castillo, P., C. Sanabria y F. Monroy. 2017. Insectos de im- 
portancia forense en cadáveres de cerdo (Sus scrofa) en La Paz Bolivia. Medicina Legal de Costa Rica, 34(1): 26-34.

Castro, M., N. Centeno and P. González-Vainer. 2019. An initial study of insect succession on pig carcasses in open pastures in the northwest of Uruguay. Forensic Science International, 302: 109837, https://doi.org/10.1016/j. forsciint.2019.05.053

Caterino, M.S. and A.K. Tishechkin. 2019. A revision of the Phelister haemorrhous species group (Coleoptera, Histeridae, Exosternini). ZooKeys, (854): 41-88.

Caterino, M.S. and A.K. Tishechkin. 2020. Recognition and revision of the Phelister blairi group (Histeridae, Histerinae, Exosternini). ZooKeys, (1001): 1-154.

Celli, N.G.R., F.W.T. Leivas, M.F.C. Caneparo y L.M. Almeida. 2015. Chave de identificação e diagnose dos Histeridae (Insecta: Coleoptera) de interesse forense do Brasil. Iheringia, Série Zoologia, 105(4):461-473.

Centeno, N., M. Maldonado and A. Oliva. 2002. Seasonal patterns of arthropods occurring on sheltered and unsheltered pig carcasses in Buenos Aires Province (Argentina). Forensic Science International, (126): 63-70.

Cline, A.R., G.S. Powell and P.R. Audisio. 2015. Beetles (Coleoptera) of Peru: A Survey of the Families. Nitidulidae. Journal of the Kansas Entomological Society, 88(2): 217-220.

Correa, C.M.A., A. Puker, V. Korasaki and K.R. Ferreira. 2013. Omorgus suberosus and Polynoncus bifurcatus (Coleoptera: Scarabaeoidea: Trogidae) in exotic and native environments of Brazil. Zoologia, 30(2): 238-241.

Correa, R.C., L.M. Almeida and M.O. Moura. 2014. Coleoptera associated with buried carrion: potential forensic importance and seasonal composition. Journal of Medical Entomology, 51(5): 1057-1066.

Correa, R.C., F.W.T. Leivas, D.P. Moura and L.M. Almeida. 2020. Necrophilous Histeridae (Insecta: Coleoptera): what do we know after 200 years? The Coleopterists Bulletin, 74(3): 635-636.

Costa-Silva, V., P.J. Thyssen y R.A. Di Mare. 2017. Levantamento da fauna de Coleoptera (Insecta) associada à carcaça de roedores na região Sul do Brasil. EntomoBrasilis, 10(3): 162-169.

Dégallier, N., G. Arriagada, M.S. Caterino, P. Kanaar, D.P. Moura, A.K. Tishechkin and W.B. Warner. 2012. (pp. 33-52). In: Coleoptera Histeridae de Guyane. VII. Compléments au catalogue avec des dones sur la faune du Surinam et une contribution à la connaissance des Saprininae. Touroult, J. (Ed.). Contribution à l'étude des Coléoptères de Guyane Tome VI. Supplément au Bulletin de Liaison d'ACOREP, France "Le Coléoptériste".

Génier, F. 2009. Le genre Eurysternus Dalman, 1824 (Scarabaeidae: Scarabaeinae: Oniticellini), révision taxonomique et clés de détermination illustrées. Pensoft Publishers, Sofia, Bulgaria.

Gines-Carrillo, E., M.A. Alcántara-Mimbela, C. Calderón-Arias, C. Infante-Valdéz y M. Villacorta-Angulo.
2015. Entomofauna de interés forense asociada a restos cadavéricos de cerdos (Sus scrofa L.), expuestos a condiciones de campo en Lambayeque - Perú. Revista Peruana de Entomología, 50(1): 1-11.

González, F.A., F. Molano y C.A. Medina. 2009. Los subgéneros Calhyboma, Hybomidium y Telhyboma (Coleoptera: Scarabaeidae: Scarabaeinae: Deltochilum) en Colombia. Revista Colombiana de Entomología, 35(2): 253-274.

Giraldo-Mendoza, A.E. 2016. Nuevos registros de Silphidae (Coleoptera) para Perú, con comentarios sobre su ecología y distribución. Arquivos Entomolóxicos, 16: $139-150$

Grados, L.E. 2014. Entomofauna asociada a la descomposición cadavérica de Sus scrofa L. (cerdo) en dos épocas del año, El Agustino, Lima, Perú. Tesis de Licenciatura, Universidad Nacional Federico Villareal, Lima.

Grisales, D., M. Ruiz and S. Villegas. 2010. Insects associated with exposed decomposing bodies in the Colombian Andean Coffee Region. Revista Brasileira de Entomologia, 54(4): 637-644.

Háva, J. and C.S. Chaboo. 2015. Beetles (Coleoptera) of Peru: A survey of the families. Nosodendridae Erichson, 1846 (Derodontoidea), Dermestidae Latreille, 1804, Bostrichidae Latreille, 1802 (Bostrichoidea). Journal of the Kansas Entomological Society, 88(3): 404-407.

Iannacone, J. 2003. Artropofauna de importancia forense en un cadáver de cerdo en el Callao, Perú. Revista Brasileira de Zoologia, 20(1): 85-90.

Kotzko, C.K., V. Costa-Silva y E.G. Silva. 2015. A importância forense de Oxelytrum discicolle (Brullé, 1840) (Coleoptera, Silphidae). Revista Brasileira de Criminalística, 4(2): 19-26.

Liria-Salazar, J. 2006. Insectos de importancia forense en cadáveres de ratas, Carabobo - Venezuela. Revista Peruana de Medicina Experimental y Salud Pública, 23(1): 33-38.

Magaña, C., C. Andara, M.J. Contreras, A. Coronado, E. Guerrero, D. Hernández, M. Herrera, M. Jiménez, C. Liendo, J. Limongi, J. Liria, M. Mavárez, M. Oviedo, J. Piñango, I. Rodríguez, A. Soto, M.F. Sandoval, J. Sánchez, N. Seijas, Z. Tiape and Y. Velásquez. 2006. Estudio preliminar de la fauna de insectos asociada a cadáveres en Maracay, Venezuela. Entomotropica, 20(1): 53-59.

Mazur, S. 2011. A concise catalogue of the Histeridae (Insecta: Coleoptera). Warsaw University of Science-SGGW Press, Warsaw.

Medina-Achín, L.J., J.E. Sosa-Neyra, M. Villacorta-Ángulo, C.Y. Santa Cruz-López y C. Calderón-Arias. 2018. Sucesión entomológica asociada a restos cadavéricos de Sus scrofa Linnaeus (Artiodactyla: Suidae) y su utilidad en la estimación del intervalo post mortem en Lambayeque, Perú. Revista Chilena de Entomología, 44 (4): 443-461.

Midgley, J.M., C.S. Richards and M.H. Villet. 2010. The 
utility of Coleoptera in forensic investigations. (pp. 5768). In: Amendt, J., M.L. Goff, C.P. Campobasso and M. Grassberger (Eds.). Current concepts in forensic entomology. Springer Publishers.

Mise, K.M., L.M. Almeida and M.O. Moura. 2007. Levantamento da fauna de Coleoptera que habita a carcaça de Sus scrofa L., em Curitiba, Paraná. Revista Brasileira de Entomologia, 51(3): 358-368.

Mise, K.M., A.S.B. Souza, C.M. Campos, R.L.F. Keppler and L.M. Almeida. 2010. Coleoptera associated with pig carcass exposed in a forest reserve, Manaus, Amazonas, Brazil. Biota Neotropica, 10(1): 321-324.

Moretti, T.C., O.B. Ribeiro, P.J. Thyssen and D.R. Solis. 2008. Insects on decomposing carcasses of small rodents in a secondary forest in Southeastern Brazil. European Journal of Entomology, (105): 691-696.

Murrugarra-Bringas, V. Y. 2016. Sucesión de artropofauna en cadáveres de cerdos (Sus scrofa L., 1758), en Pantanos de Villa, Chorrillos, Lima, Perú. Tesis de Maestría, Universidad Nacional Mayor de San Marcos, Lima.

Nadeau, P., M. Thibault, F.G. Horgan, J.-P. Michaud, F. Gandiaga, C. Comeau and G. Moreau. 2015. Decaying matters: Coleoptera involved in heterotrophic systems. (pp. 123-174). In: Stack, C. (Ed.). Beetles: Biodiversity, Ecology and Role in the Environment. Nova Science Publishers.

Navarrete-Heredia, J.L. 2004. Sinopsis del género Xanthopygus Kraatz, 1857 (Coleoptera: Staphylinidae) de México. Acta Zoológica Mexicana (n.s.), 20(3): 1-13.

Navarrete-Heredia, J.L., A.F. Newton, M.K. Thayer, J.S. Ashe and D.S. Chandler. 2002. Guía ilustrada para los géneros de Staphylinidae (Coleoptera) de México. Universidad de Guadalajara y CONABIO, México.

Newton, A.F. 2015. Beetles (Coleoptera) of Peru: A survey of the families. Staphylinidae Latreille, 1802. Journal of the Kansas Entomological Society, 88(2): 283-304.

Oliva, A. 2001. Insects of forensic significance in Argentina. Forensic Science International, (120): 145-154.

Ospina-Maldonado, L. 2006. Determinación taxonómica de la entomofauna asociada a cadáveres inhumados de cerdo (Sus scrofa) coleccionada durante el primer semestre del año 2005, en el municipio Villeta - Cundinamarca. Tesis de Licenciatura, Universidad de los Andes, Bogotá DC.

Özdemir, S. and O. Sert. 2009. Determination of Coleoptera fauna on carcasses in Ankara province, Turkey. Forensic Science International, (183): 24-32.

Peceros-Peláez, F.M.E. 2011. Sucesión entomológica asociada a procesos de descomposición de carcasas de cerdo (Sus scrofa L., 1758) en la provincia de Huarochirí. Tesis de Licenciatura, Universidad Nacional Mayor de San Marcos, Lima.

Pizango-Pérez, J., F.M. Cachi-Rios, A. Acosta-Diaz, R. Zárate-Gómez y E. Gines-Carrillo. 2019. Entomofauna de interés forense asociada a la descomposición de Sus scrofa domesticus (cerdo doméstico) en la Amazonía peruana. Ciencia Amazónica (Iquitos), 7 (1): 21-36.

Ramos-Pastrana, Y., Y. Virgüez-Díaz and M. Wolff. 2018. Insects of forensic importance associated to cadaveric decomposition in a rural area of the Andean Amazon, Caquetá, Colombia. Acta Amazonica, 48: 126-136.

Ratcliffe, B.C. 2013. The dung- and carrion-feeding scarabs (Coleoptera: Scarabaeoidea) of an Amazonian blackwater rainforest: results of a continuous, 56-week, baited-pitfall trap study. The Coleopterists Bulletin, 67(4): 481-520.

Ratcliffe, B.C., M.L. Jameson, L. Figueroa, R.D. Cave, M.J. Paulsen, E.B. Cano, C. Beza-Beza, L. Jiménez-Ferbans and P. Reyes-Castillo. 2015. Beetles (Coleoptera) of Peru: A Survey of the Families. Scarabaeoidea. Journal of the Kansas Entomological Society, 88(2): 186-207.

Remedios-De León, M., M. Castro y E. Morelli. 2017. Artropodofauna cadavérica sobre modelos experimentales porcinos Sus scrofa Linnaeus, 1758 (Mammalia: Artiodactyla) en cuatro periodos estacionales. Entomología Mexicana, 4: 550-559.

Ries, A.C.R., V.C. Silva, P.G. da Silva, B. Blochtein and P.J. Thyssen. 2016. Record of Ataenius picinus Harold, 1868 (Coleoptera: Scarabaeidae: Aphodiinae) associated with exposed carcasses in Southern Brazil. Entomotropica, 31(6): 48-53.

Rodríguez-Olivares, K.P., S. Quijas, F.G. Cupul-Magaña y J.L. Navarrete-Heredia. 2015. Literatura científica sobre artrópodos asociados a cadáveres: estudio observacional. Acta Universitaria, 25(6): 20-29. doi: 10.15174/ au.2015.824

Salazar, F. y D.A. Donoso. 2015. Catálogo de insectos con valor forense en el Ecuador. REMCB, (36): 49-59.

Santos, W.E., A.C.F. Alves and A.J. Creão-Duarte. 2014. Beetles (Insecta, Coleoptera) associated with pig carcasses exposed in a Caatinga area, Northeastern Brazil. Brazilian Journal of Biology, 74(3): 649-655.

Santos, W.E., A.C.F. Alves and A.J. Creão-Duarte. 2019. Performance of sampling methods of Coleoptera associated with carcasses. Entomotropica, (34): 1-7.

Sarmiento-Yengle, V. y S. Padilla-Sagástegui. 2015. Sucesión entomológica asociada a procesos de descomposición en cadáveres de Oryctolagus cuniculus en condiciones de campo, Trujillo, La Libertad, 2014. Sciendo, 17(1): 134-140.

Sawaby, R.F., H. EL Hamouly and R.H. Abo-El Ela. 2016. Taxonomic study of the main families of Egyptian Coleoptera with forensic importance. Life Science Journal, 13(4): 39-53.

Scampini, E., A. Cicchino y N. Centeno. 2002. Especies de Carabidae (Coleoptera) asociadas a cadáveres de cerdo (Sus scrofa) en Santa Catalina (Buenos Aires, Argentina). Revista de la Sociedad Entomológica Argentina, 61(3-4): 85-88.

Scholtz, C.H. 1990. Revision of the Trogidae of South America (Coleoptera: Scarabaeoidea). Journal of Natural History, (24): 1391-1456. 
Silva, R.C. and W.E. Santos. 2012. Fauna de Coleoptera associada a carcaças de coelhos expostas em uma área urbana no Sul do Brasil. EntomoBrasilis, 5(3): 185-189.

Souza, A.M. and A.X. Linhares. 1997. Diptera and Coleoptera of potential forensic importance in southeastern Brazil: relative abundance and seasonality. Medical and Veterinary Entomology, (11): 8-12.

Souza, A.S.B., F.D. Kirst and R.F. Krüger. 2008. Insects of forensic importance from Rio Grande do Sul state in southern Brazil. Revista Brasileira de Entomologia, 52(4): 641-646.

Tishechkin, A.K. and N. Dégallier. 2015. Beetles (Coleoptera) of Peru: A survey of the families. Histeridae. Journal of the Kansas Entomological Society, 88(2): 173-179.

Trigo, A.V. and N. Centeno. 2014. Abnormal succession of insect fauna on pig carcasses in Tandil (Argentina, Buenos Aires Province). Advances in Entomology, (2): 102-113.

Ururahy-Rodrigues, A., J.A. Rafael, J.R. Pujol-Luz, A. L. Henriques, M.M. C. Queiroz, R.R. Barbosa and M.N. Baroni. 2010. Association of Oxelytrum cayennense (Silphidae, Coleoptera) with pig carcasses (Sus scrofa, Suidae) in Terra Firme Areas in Manaus, Amazonas, Brazil. EntomoBrasilis, 3(2): 45-48.

Recibido: 21 febrero 2021

Aceptado: 22 marzo 2021
Ururahy-Rodrigues, A., J. A. Rafael, R.F. Wanderley, H. Marques and J.R. Pujol-Luz. 2008. Coprophanaeus lancifer (Linnaeus, 1767) (Coleoptera, Scarabaeidae) activity moves a man-size pig carcass: Relevant data for forensic taphonomy. Forensic Science International, (182): 19-22.

Vasconcelos, S.D. and M.C.S. Araujo. 2012. Necrophagous species of Diptera and Coleoptera in northeastern Brazil: state of the art and challenges for the forensic entomologist. Revista Brasileira de Entomologia, 56(1): 7-14.

Wolff, M., A. Uribe, A. Ortiz and P. Duque. 2001. A preliminary study of forensic entomology in Medellín, Colombia. Forensic Science International, (120): 53-59.

Zanetti, N.I., R. Camina, E.C. Visciarelli and N.D. Centeno. 2016. Active search on carcasses versus pitfall traps: a comparison of sampling methods. Neotropical Entomology, 45(2): 221-226.

Zanetti, N.I., A.A. Ferrero and N.D. Centeno. 2018. Depressions of Dermestes maculatus (Coleoptera: Dermestidae) on bones could be pupation chambers. The American Journal of Forensic Medicine and Pathology, 40(2): 122-124.

Zanetti N. I., E.C. Visciarelli and N.D. Centeno. 2015a. Trophic roles of scavenger beetles in relation to decomposition stages and seasons. Revista Brasileira de Entomologia, (59): 132-137.

Zanetti N. I., E.C. Visciarelli and N.D. Centeno. 2015b. Marks caused by the scavenging activity of Necrobia rufipes (Coleoptera: Cleridae) under laboratory conditions. Journal of Forensic and Legal Medicine, (33): 116-120. 
Appendix 1. Summary of studies about entomological cadaveric succession in South America.

\begin{tabular}{|c|c|c|c|c|}
\hline & locality & substrates & collecting methods & references \\
\hline 1 & Campinas city, Sao Paulo, Brazil & pig carcasses & $\begin{array}{l}\text { Shannon traps (named coni- } \\
\text { cal), underneath tray }\end{array}$ & $\begin{array}{l}\text { Souza and Linhares } \\
(1997)\end{array}$ \\
\hline 2 & Medellín city, Antioquia, Colombia & pig carcasses & manual collecting & Wolff et al. (2001) \\
\hline 3 & $\begin{array}{l}20 \mathrm{~km} \text { SE from Buenos Aires city, Argen- } \\
\text { tina }\end{array}$ & pig carcasses & $\begin{array}{l}\text { manual collecting, pitfall } \\
\text { traps }\end{array}$ & Centeno et al. (2002) \\
\hline 4 & Ventanilla, Callao, Perú & pig carcasses & manual collecting & Iannacone (2003) \\
\hline 5 & $\begin{array}{l}\text { Carabobo University, Carabobo, Venezu- } \\
\text { ela }\end{array}$ & rat carcasses & $\begin{array}{l}\text { underneath tray, substrate ex- } \\
\text { traction }\end{array}$ & Liria-Salazar (2006) \\
\hline 6 & Maracay city, Aragua, Venezuela & rabbit and rat carcasses & manual collecting & Magaña et al. (2006) \\
\hline 7 & Villeta, Cundinamarca, Colombia & pig carcasses & manual collecting & $\begin{array}{l}\text { Ospina-Maldonado } \\
(2006)\end{array}$ \\
\hline 8 & Curitiba, Paraná, Brazil & pig carcasses & $\begin{array}{l}\text { underneath tray, Shannon } \\
\text { trap, pitfall trap }\end{array}$ & Mise et al. (2007) \\
\hline 9 & San Juan Province, Argentina & $\begin{array}{l}\text { pig carcasses, open air } \\
\text { vertebrate carcasses }\end{array}$ & $\begin{array}{l}\text { manual collecting, Malaise } \\
\text { trap }\end{array}$ & Aballay et al. (2008) \\
\hline 10 & Campinas city, Sao Paulo, Brazil & mice and rat carcasses & $\begin{array}{l}\text { manual collecting, substrate } \\
\text { extraction }\end{array}$ & Moretti et al. (2008) \\
\hline 11 & Rio Grande do Sul, Brazil & rabbit carcasses & manual collecting & Souza et al. (2008) \\
\hline 12 & Pereira city, Risaralda, Colombia & pig carcasses & manual collecting & Grisales et al. (2010) \\
\hline 13 & Adolpho Ducke Forest Reserve, Brazil & pig carcasses & $\begin{array}{l}\text { manual collecting, pitfall } \\
\text { traps }\end{array}$ & Mise et al. (2010) \\
\hline 14 & Huarochirí, Lima, Perú & pig carcasses & $\begin{array}{l}\text { manual collecting, undernea- } \\
\text { th tray }\end{array}$ & $\begin{array}{l}\text { P ec e r o s - P e lá e z } \\
(2011)\end{array}$ \\
\hline 15 & SJNU campus, San Juan, Argentina & pig carcasses & $\begin{array}{l}\text { manual collecting, Malaise } \\
\text { trap, pitfall traps }\end{array}$ & Aballay et al. (2012) \\
\hline 16 & Ribeirão do Pinhal, Paraná, Brazil & rabbit carcasses & $\begin{array}{l}\text { underneath tray, Shannon } \\
\text { trap, pitfall traps }\end{array}$ & $\begin{array}{l}\text { Silva and Santos } \\
(2012)\end{array}$ \\
\hline 17 & Pichincha province, Ecuador & guinea pig carcasses & $\begin{array}{l}\text { manual collecting, McPhail } \\
\text { trap, pitfall traps }\end{array}$ & $\begin{array}{l}\text { Aguirre-Carrera } \\
(2014)\end{array}$ \\
\hline 18 & Mata Viva reserve, Paraná, Brazil & rabbit carcasses & $\begin{array}{l}\text { substrate extraction, pitfall } \\
\text { traps }\end{array}$ & Correa et al. (2014) \\
\hline 19 & El Agustino, Lima, Perú & pig carcasses & manual collecting & Grados (2014) \\
\hline 20 & Fazenda Almas reserve, Paraíba, Brazil & pig carcasses & $\begin{array}{l}\text { underneath tray, Shannon } \\
\text { trap, pitfall traps }\end{array}$ & Santos et al. (2014) \\
\hline 21 & Tandil, Buenos Aires, Argentina & pig carcasses & manual collecting & $\begin{array}{l}\text { Trigo and Centeno } \\
(2014)\end{array}$ \\
\hline 22 & Puerto Madryn, Chubut, Argentina & pig carcasses & $\begin{array}{l}\begin{array}{l}\text { manual collecting, pitfall } \\
\text { traps }\end{array} \\
\end{array}$ & Armani et al. (2015) \\
\hline 23 & $\begin{array}{l}\text { UNPRG botanic garden, Lambayeque, } \\
\text { Perú }\end{array}$ & pig carcasses & manual collecting & $\begin{array}{l}\text { Ginés-Carrillo et al. } \\
(2015)\end{array}$ \\
\hline 24 & Experimental field UNT, La Libertad, Perú & rabbit carcasses & manual collecting & $\begin{array}{l}\text { Sarmiento-Yengle } \\
\text { and Padilla-Sagáste- } \\
\text { gui (2015) }\end{array}$ \\
\hline 25 & Pantanos de Villa, Lima, Perú & pig carcasses & manual collecting & $\begin{array}{l}\text { Murrugarra-Bringas } \\
(2016)\end{array}$ \\
\hline 26 & Telteca reserve, Mendoza, Argentina & cow and horse carcasses & substrate extraction & Aballay et al. (2017) \\
\hline 27 & Trelew city, Chubut, Argentina & pig carcasses & $\begin{array}{l}\text { manual collecting, pitfall } \\
\text { traps }\end{array}$ & Armani et al. (2017) \\
\hline 28 & Pucarani, La Paz, Bolivia & pig carcasses & manual collecting & Castillo et al. (2017) \\
\hline 29 & Santa Maria, Rio Grande do Sul, Brazil & rat carcasses & $\begin{array}{l}\text { manual collecting, pitfall } \\
\text { traps }\end{array}$ & $\begin{array}{l}\text { Costa-Silva et al. } \\
(2017)\end{array}$ \\
\hline
\end{tabular}


A preliminary list of beetles (Insecta: Coleoptera) of forensic importance from Peru

\begin{tabular}{|l|l|l|l|l|}
\hline 30 & Pando city, Canelones, Uruguay & pig carcasses & $\begin{array}{l}\text { manual collecting, Malaise } \\
\text { trap, pitfall traps }\end{array}$ & $\begin{array}{l}\text { Remedios-De León et } \\
\text { al. }(2017)\end{array}$ \\
\hline 31 & Caserío Miraflores, Castilla, Piura, Perú & guinea pig carcasses & manual collecting & $\begin{array}{l}\text { Andrade-Herrera et } \\
\text { al. }(2018)\end{array}$ \\
\hline 32 & $\begin{array}{l}\text { UNPRG botanic garden, Lambayeque, } \\
\text { Perú }\end{array}$ & pig carcasses & manual collecting & $\begin{array}{l}\text { Medina-Achín et al. } \\
(2018)\end{array}$ \\
\hline 33 & Florencia, Caquetá, Colombia & pig carcasses & $\begin{array}{l}\text { manual collecting, pitfall } \\
\text { traps }\end{array}$ & $\begin{array}{l}\text { Ramos-Pastrana et al. } \\
(2018)\end{array}$ \\
\hline 34 & Paysandú city, Paysandú, Uruguay & pig carcasses & $\begin{array}{l}\text { manual collecting, Malaise } \\
\text { trap, pitfall traps }\end{array}$ & Castro et al. (2019) \\
\hline 35 & San Juan Bautista, Maynas, Loreto, Perú & pig carcasses & manual collecting & $\begin{array}{l}\text { Pizango-Pérez et al. } \\
(2019)\end{array}$ \\
\hline
\end{tabular}

Appendix 2. Summary of species, frequency, ratio and index for each genus. Numbers already mentioned in results and discussion section is highlighted in bold.

\begin{tabular}{|c|c|c|c|c|c|c|c|}
\hline \multirow{2}{*}{ Family/genus } & \multicolumn{4}{|l|}{ species } & \multirow{2}{*}{$\begin{array}{l}\text { frequency } 35 \\
\text { studies }\end{array}$} & \multirow[t]{2}{*}{ ratio } & \multirow[t]{2}{*}{ index } \\
\hline & known & expected & potential & In Peru & & & \\
\hline \multicolumn{8}{|l|}{ Cleridae } \\
\hline Necrobia & 2 & 0 & 0 & 2 & 0.71 & 1.00 & 0.50 \\
\hline \multicolumn{8}{|l|}{ Dermestidae } \\
\hline Dermestes & 3 & 3 & 0 & 6 & 0.80 & 1.00 & 0.40 \\
\hline \multicolumn{8}{|l|}{ Histeridae } \\
\hline Hister & 0 & 1 & 0 & 6 & 0.46 & 0.17 & 0.05 \\
\hline Omalodes & 0 & 3 & 0 & 9 & 0.11 & 0.33 & 0.10 \\
\hline Phelister & 0 & 1 & 3 & 39 & 0.20 & 0.10 & 0.02 \\
\hline Euspilotus & 2 & 4 & 4 & 14 & 0.63 & 0.71 & 0.21 \\
\hline Saprinus & 1 & 0 & 0 & 1 & 0.23 & 1.00 & 0.50 \\
\hline Xerosaprinus & 1 & 1 & 0 & 2 & 0.17 & 1.00 & 0.40 \\
\hline \multicolumn{8}{|l|}{ Nitidulidae } \\
\hline Carpophilus & 0 & 1 & 0 & 6 & 0.14 & 0.17 & 0.05 \\
\hline Stelidota & 0 & 1 & 0 & 3 & 0.11 & 0.33 & 0.10 \\
\hline \multicolumn{8}{|l|}{ Scarabaeidae } \\
\hline Ataenius & 0 & 1 & 0 & 30 & 0.17 & 0.03 & 0.01 \\
\hline Canthidium & 0 & 0 & 0 & 23 & 0.14 & --- & --- \\
\hline Canthon & 3 & 8 & 0 & 38 & 0.20 & 0.29 & 0.10 \\
\hline Coprophanaeus & 0 & 1 & 2 & 9 & 0.17 & 0.33 & 0.08 \\
\hline Deltochilum & 0 & 4 & 3 & 21 & 0.14 & 0.33 & 0.09 \\
\hline Dichotomius & 0 & 2 & 2 & 33 & 0.17 & 0.12 & 0.03 \\
\hline Eurysternus & 0 & 3 & 4 & 19 & 0.14 & 0.37 & 0.09 \\
\hline Ontherus & 0 & 1 & 0 & 18 & 0.14 & 0.06 & 0.02 \\
\hline Onthophagus & 0 & 1 & 1 & 17 & 0.20 & 0.12 & 0.03 \\
\hline \multicolumn{8}{|l|}{ Silphidae } \\
\hline Oxelytrum & 1 & 2 & 0 & 3 & 0.40 & 1.00 & 0.37 \\
\hline \multicolumn{8}{|l|}{ Staphylinidae } \\
\hline Aleochara & 0 & 4 & 0 & 19 & 0.29 & 0.21 & 0.06 \\
\hline Atheta & 0 & 0 & 0 & 12 & 0.11 & --- & --- \\
\hline Anotylus & 0 & 0 & 0 & 3 & 0.11 & -- & --- \\
\hline
\end{tabular}


Alfredo Edgardo Giraldo-Mendoza

\begin{tabular}{|c|c|c|c|c|c|c|c|}
\hline Belonuchus & 0 & 1 & 0 & 21 & 0.11 & 0.05 & 0.01 \\
\hline Creophilus & 0 & 2 & 0 & 2 & 0.23 & 1.00 & 0.30 \\
\hline Eulissus & 0 & 1 & 0 & 3 & 0.14 & 0.33 & 0.10 \\
\hline Philonthus & 0 & 4 & 0 & 21 & 0.43 & 0.19 & 0.06 \\
\hline Platydracus & 0 & 3 & 0 & 18 & 0.14 & 0.17 & 0.05 \\
\hline Xanthopygus & 0 & 0 & 1 & 8 & 0.17 & 0.13 & 0.03 \\
\hline \multicolumn{8}{|l|}{ Trogidae } \\
\hline Omorgus & 1 & 0 & 1 & 2 & 0.29 & 1.00 & 0.35 \\
\hline Polynoncus & 0 & 0 & 6 & 6 & 0.14 & 1.00 & 0.20 \\
\hline
\end{tabular}

